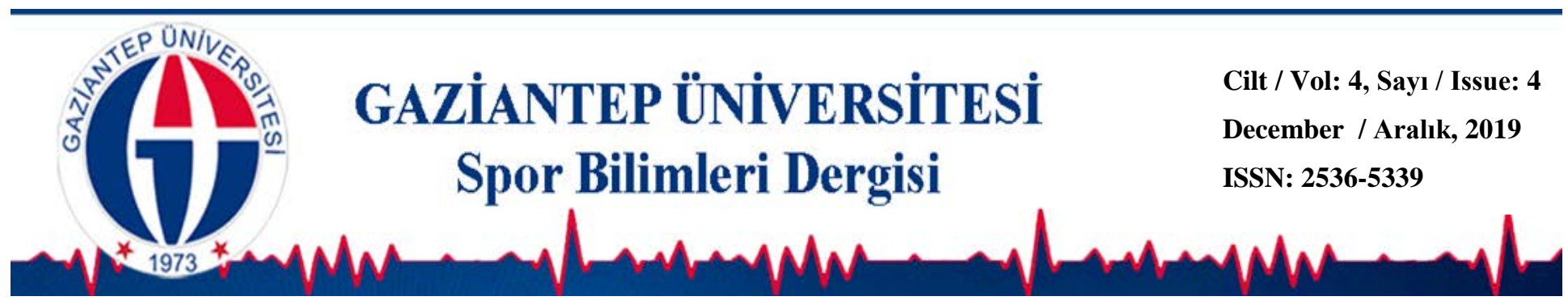

The Effect of 12-week Training Program on Attention Levels of Racket Athletes

\title{
Yeliz DOĞRU*
}

${ }^{1}$ İzmir Katip Çelebi University, Department of Sports, IZMIR

\section{DOI: 10.31680/gaunjss.638294}

Orijinal Makale / Original Article

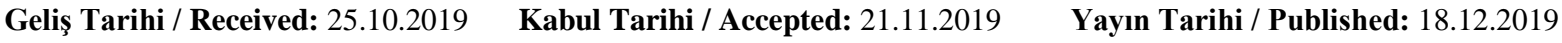

\begin{abstract}
Attention and decision-making strategies are two elements that play a significant role in the best way to display the performance in sport. Therefore, the aim of this study was to determine the effect of 12week training program on attention levels of racket athletes. 70 volunteers participated in the study between 18-25 years. Participants were divided into three groups as table tennis group (TTG, $n=25$ ), badminton group (BG, $n=23$ ) and tennis group ( $T G, n=22$ ). D2 attendance test was performed before and after 12 weeks. The exercise program was applied to all groups three days a week for twelve weeks. The results were analyzed with the SPSS package program. There was a statistically significant difference between the pre-test and post-test data in groups $(p<0.05)$. There was no significant difference between the three groups ( $p>0.05)$. As a result, it is possible to say that 12-week exercise programs have positive effects on the attention levels of racket athletes.
\end{abstract}

Keywords: d2 test of attention, Table Tennis, Badminton, Tennis

\footnotetext{
* Sorumlu Yazar: Yeliz Doğru
} 


\section{Introduction}

Caution is that the mind has a clear and distinct adopt of one of the objects or ideas that emerge at the same time. On the basis of attention, focus, concentration and consciousness factors are seen to be effective (Solso et al., 2007). Due to the brain has a limited capacity, most of the external stimuli are captured by the sensory organs. It allows the brain to selectively detect some of the stimuli that come with the effect of certain variables. In order to the performance of sport to be successful and to demonstrate it successfully, athletes should provide concentration to the relevant stimuli by ignoring the aimed at stimuli at this stage. Stress will occur before and during the competition of the athletes. In spite of psychological pressures, if the concentration continues throughout the competition, their success will increase. Some psychological processes that occur during the sport, attention, detection, imagination and thinking are all possible to define these functions as conscious attention. The intensity of attention manifests itself as the ability to create this conscious movement (LaGarde et al., 2010).

Through long ages, it has been known that the concept of attention is effective in learning any motor ability. As a science, motor learning is defined as follows; it is the conscious or unconscious increase of the perception required for attention performance (Schefke and Gronek, 2010). The sport has been the focus of interest for selective attention. According to Singer et al. (1991), in order to successfully demonstrate psychomotor skills, individuals should be able to selectively focus and concentrate on relevant stimuli while ignoring unrelated stimuli. In any whatever situation, the organism is constantly bombarded with information from both internal and external environments and can only assimilate a certain amount of it. Therefore, selectivity is only required for the processing of a few stimuli. It is seen that the ability to direct attention to the appropriate stimulus and to continue to pay attention is an important factor for success in sports (Singer et al., 1991). Ability is to learn difficult movements in a short time. It is also able to react quickly in different situations to the purpose. Each movement depends on the correct monitoring of each other and the desired strength. The skillful movement occurs when the stimuli from the central nervous system arrive at the muscles that need to contract. In the sense of sporting, coordination is the implementation of voluntary and involuntary movements in a regular, coherent, goal-oriented sequence of movements, and is a neural power of 
the organism. In other words, coordination is the cooperation between the skeletal muscles, joints and joints and the central nervous system involved in the implementation of the movement (Sevim, 2007). Recently, there is increasing evidence that acute physical activity may positively affect cognitive performance not only in adults6, but also in children and adolescents (Hillman et al., 2009; Verburgh et al; 2014).

The number of carefully related studies in sports is increasing. In order to athletes to reach the targeted level of performance, they should be able to distinguish the stimuli from the most necessary to the most necessary and use their attention in the most effective way. Human beings are constantly in charge of internal and external information and can only internalize a certain amount of them. In short, the mind needs to make a choice in order to distinguish the correct stimuli. Mind, speed of reaction, attention, and concentration are particular components of cognition (Gallotta et al., 2012). Attention and decision making is important for the athletes and coaches in the best way to display the performance in sport. Attention and decisionmaking strategies are two elements that play an important role. Both skills have the ability to process information quickly. Therefore, attention and decision-making strategies are very important in demonstrating sporting skills. The ability to direct attention to the appropriate stimulus for success in sports and to continue to pay attention is an important factor. Attention is the behavioral and cognitive process of selectively concentrating on one aspect of the environment while ignoring other things. The athlete's attention and concentration should be evaluated. Behavioral, cognitive and physiological analysis levels are used to better understand the phenomenon of attention in sports and exercise psychology (Vanhelst et al., 2016).

Based on this information, the purpose of this study was to determine the effect of 12-week training program on attention levels of table tennis, badminton and tennis athletes.

\section{Method}

University students participated in the study voluntarily between 18-25 years. Participants who were invited by way of the face-to-face meeting were informed about the purpose and content of the study. The study was conducted in accordance with the principles of Helsinki Declaration. Students who had at least 5 years 
experience in table tennis, badminton and tennis were included in the study. Before beginning the implementation phase of the study, all participants signed a form that they agreed to voluntarily participate in the study. Table tennis $(n=25)$, badminton $(n=23)$ and tennis $(n=22)$, the participants were divided into three groups.

\section{Training Protocol}

Table tennis athletes have been given training on backhand-forehand strokes, service receive, spin, lop, block, cutting techniques for three days a week along twelve weeks. The program has been carried out like ten minutes of warming, sixty minutes of training and ten minutes of cooling. Tennis athletes were given a training program for backhand-forehand strokes, ball-pointing, racket-grip, swing, service, and receiver techniques for three days a week along twelve weeks. The program has been carried out like 10 minutes of warming, 60 minutes of training and 10 minutes of cooling. Badminton athletes were given training program for backhand-forehand strokes, racket grip, splash, service, and receiver techniques for three days a week along twelve weeks. The program has been carried out like 10 minutes of warming, 60 minutes of training and 10 minutes of cooling.

\section{D2 Test of Attention}

Test was developed by Brickenkamp in 1962. It has undergone different revisions in the later years. The goal of the test is to measure the sustained attention and visual scanning capabilities. The $\mathrm{d} 2$ test is a measure of mental concentration and selective attention. In the manuel of the test "attention and concentration", it was used as a performance-oriented, continuous and focused on selecting a stimulus. Test has been developed to distinguish drivers but is currently used to measure attention in different areas (such as education, psychopharmacology, industry, clinical, sports psychology). The test page has consisted of fourteen lines, each of consist of forty-seven marked letters. Each line has 16 different letters consisting of the letters "p" and "d" with one, two, three and four small signs. The subject must ignore the other non-related letters and scan the lines to find and draw the two "d" letters during the test. For each line, the subject is given 20 seconds. Test can be applied individually or as a group (Brieckamp and Zillmer, 1998). 
Total Number of Commodities Processed (TN): It is a quantitative measurement of the performance of all relevant and non-related substances. Total Error (E): Includes unmarked (E1) and incorrectly marked letters (E2). Error Percent $(\% \mathrm{E})$ : A variable that measures the qualitative aspect of performance. Represents the error rate within all the treated items. As the error rate decreases, the accuracy of the subject, the nature of the work and the degree of caution increases. Concentration Performance (CP): From the number of relevant items marked as true it is obtained by removing E2. Fluctuation Ratio (FR): This is the difference between the number of items with the maximum number of items and the minimum number of items. Total Substance-Error (TN-E): The total number of items scanned is negative error points. TN-E is a total reliable performance score. It gives a measure of the relationship between accuracy and speed of performance. The obtained TN-E is defined as $50-60 \%$ bad, $60-70 \%$ mediocre, $70-85 \%$ normal and $85 \%$ above the percentage is good of the score (Çağlar and Koruç, 2006).

\section{Statistical Analysis}

The data collected from the participants were analyzed with SPSS 22.00 package program. The data were evaluated by the Shapiro-Wilk test for normal distribution. Mann Whitney $U$ test was used to compare the groups in the data that did not show normal distribution. In the pre-post test comparison, Wilcoxon signed rank test was applied. Significance was accepted at $p<0.05$.

\section{Results}

The descriptive data of the participants are shown in Table 1.

Table 1. General characteristics of participants at baseline.

\begin{tabular}{lcccccc}
\hline \multirow{2}{*}{ Parameters } & \multicolumn{2}{c}{ TTG (n=25) } & \multicolumn{2}{c}{ BG (n=23) } & \multicolumn{2}{c}{ TG (n=22) } \\
\cline { 2 - 7 } & Min-Max & Mean \pm SD & Min-Max & Mean \pm SD & Min-Max & Mean \pm SD \\
Age (yr) & $18-25$ & $20.11 \pm 2.12$ & $18-25$ & $22.01 \pm 3.4$ & $18-25$ & $21.2 \pm 7.1$ \\
Height (cm) & $165-178$ & $173.45 \pm 1.75$ & $169-185$ & $177.22 \pm 3.45$ & $167-187$ & $178.4 \pm 6.1$ \\
$\begin{array}{l}\text { Body weight } \\
\text { (kg) }\end{array}$ & $69.1-82.3$ & $75.2 \pm 3.27$ & $66.4-86.4$ & $78.4 \pm 8.61$ & $65.6-89.1$ & $79.45 \pm 7.41$ \\
\hline
\end{tabular}


Table 2 shows the pre- and post-exercise comparisons of the participants. Accordingly, there was a statistically significant difference between the pre-test and post-test data in three groups $(p<0.05)$. There was no difference between the groups in the comparison between the three groups $(p<0.05)$.

Table 2. Changes in $\mathrm{d} 2$ test of subjects following the intervention

\begin{tabular}{lccccc}
\hline Parameters & n & Pre-test & Post-test & $\begin{array}{c}\text { Within group } \\
\text { p }\end{array}$ & $\begin{array}{c}\text { Between } \\
\text { group }\end{array}$ \\
\hline E total & & & & & \\
TTG & 25 & $15.5 \pm 46.1$ & $7.12 \pm 212.4$ & $.005^{*}$ & .352 \\
BG & 23 & $16.4 \pm 75.41$ & $8.41 \pm 55.7$ & $.006^{*}$ & \\
TG & 22 & $18.1 \pm 44.7$ & $10.2 \pm 122.4$ & $.011^{*}$ & \\
CP & & & & & \\
TTG & 25 & $142 \pm 245.44$ & $212 \pm 122.23$ & $.004^{*}$ & .451 \\
BG & 23 & $147 \pm 46.86$ & $206 \pm 64.44$ & $.004^{*}$ & \\
TG & 22 & $152 \pm 247.6$ & $201 \pm 86.54$ & $.005^{*}$ & \\
TN_E & & & & & \\
TTG & 25 & $365 \pm 39.45$ & $490 \pm 68.7$ & $.003^{*}$ & .123 \\
BG & 23 & $358 \pm 62.21$ & $472 \pm 121.4$ & $.003^{*}$ & \\
TG & 22 & $350 \pm 77.12$ & $460 \pm 48.1$ & $.004^{*}$ & \\
*p $<0.05$ change from baseline & & & & &
\end{tabular}

\section{Discussion and Conclusion}

According to the results of our study, table tennis, badminton, and tennis training had a positive effect on attention levels.

Fontani et al (2016), karate and volleyball branches of experienced and inexperienced athletes applied their attention and memory test. According to these results, experienced volleyball athletes have noticed that their performance is higher than the athletes with less experience. One study examined the motor skills of the coordination of male basketball players at different levels. It has been observed that the athletes who have high performance levels have a positive impact on the performance of their decision making and making decisions, as well as motor skills (Jerzy et al., 2015).

In the literature, a study was performed comparing elite male basketball players $(n=13)$ and the cognitive characteristics of two groups without basketball experience $(n=15)$. According to the study, the memory and selective attention 
performance of elite basketball players were found to be better than the control group (Kioumourtzoglou et al., 1998). Memmert et al. (2009), examined the relationship between experienced handball athletes with visual attention performance, unlike other studies, experienced handball athletes were not better than the inexperienced handball players athletes.

Asan (2011) study, 80 children aged 9-13 years participated in the study. The children in the study are divided into table tennis and non-table tennis. While there was no significant difference in the pre-test results at the children's attention levels, the results of the final test results were in favor of the children who were practicing table tennis. In this study, the increase in the attention level of the participants after 3 months of training period supports the literature.

Özdemir (1990), compared the level of attention of university students, athletes, and non-athletes. As a result of the research, it was revealed that students who are athletes are more careful than non-athletes.

A study was carried out to investigate the levels of attention of individuals who were 14-15 years old. As a result of the comparison of the pre-test and post-test values of the volunteers in the study, the pretest value of the experimental group was $77.10 \pm 11.813$ and the final test value was $91.13 \pm 10.023$. In the control group, the pretest value was $70.97 \pm 15.912$ and the final test value was $72.30 \pm 15.093$. A comparison was made between the experimental group and the control group final test values. A statistically significant difference was found $(p<0.05)$. This showed that the golf exercises applied to the experimental group positively affect the attention levels of individuals (Tunç, 2013).

Kartal et al (2016), compared the attention performance of 20 children who are engaged in fencing sport in 10-12 age schools and 20 children who do not exercise regularly. It has been found that children who have fencing sports have better levels of attention than those who do not. Again, in the study conducted on 115 school children aged 9-10 years, D2 attention performance test was applied before and after 30 minutes of acute aerobic exercise. In the results of the D2 attention performance test, it was recorded that there was an increase after sports training (Chen, 2017). Studies in the literature emphasize the positive effect of exercise on attention.

In another study conducted by Kumartaşlı and Baştuğ (2010) about the level of attention of athletes, a total of 90 samples from three different martial sports 
(Taekwondo, Karate, Muayhtai) aged between 10 and 20 were examined. As a result of this research, it was concluded that there was no significant difference between the participants' age, gender, sports branch and attention levels. In conclusion, the effect of the 12-week exercise program on attention in this study supports the studies in the literatüre.

\section{References}

Asan R. (2011). Sekiz haftalık masa tenisi egzersizinin 9-13 yaş arası çocuklarda dikkat üzerine etkisi. Selçuk Üniversitesi Sağlık Bilimleri Enstitüsü Doktora Tezi.

Brieckamp R, Zillmer E. (1998). The d2 test of attention. Seattle, Washington: Hogrefe \& Huber Publishers.

Çağlar E, Koruç Z. (2006). D2 dikkat testinin sporcularda güvenirliği ve geçerliği. Spor Bilimleri Dergisi.17(2), 58-80.

Chen W, Zhang Z, Callaghan B, LaChappa L, Chen M, He Z. (2017). Acute effects of aerobic physical activities on attention and concentration in school-aged children. Biomed J Sci \& Tech Res.1(5), 1-8.

Fontani G, Lodi L, Felici A, Migliorini S, Corradeschi F. (2006). Attention in athletes of high and low experience engaged in different open skill sports. Perceptual and Motor Skills.102(3), 791-805.

Gallotta MC, Guidetti L, Franciosi E, Emerenziani GP, Bonavolonta V, Baldari C. (2012). Effects of varying type of exertion on children's attention capacity. Medicine and science in sports and exercise. 44(3), 550-555.

Hillman CH, Pontifex MB, Raine LB, Castelli DM, Hall EE, Kramer AF. (2009). The effect of acute treadmill walking on cognitive control and academic achievement in preadolescent children. Neuroscience.159, 1044-54.

Jerzy S, Paweł W, Janusz Z, Tomasz N, Mariusz B. (2015). Structure of coordination motor abilities in male basketball players at different levels of competition. Polish Journal of Sport and Tourism. 21(4), 234-39.

Kartal R, Dereceli Ç, Kartal A. (2016). Eskrim sporu yapan ve yapmayan 10-12 yaş arası çocukların dikkat düzeylerinin incelenmesi. Sportif Bakış: Spor ve Eğitim Bilimleri Dergisi. 3(2), 82-88. 
Kioumourtzoglou E, Derri V, Tzetzls G, Theodorakis Y. (1998). Cognitive, perceptual, and motor abilities in skilled basketball performance. Perceptual and motor skills. 86(3), 771-786.

Kumartasli M, Baştuğ G. (2010). Examination of attention levels of athletes who do Taekwondo, Karate and Muaythai. Ovidius University Annals, Series Physical Education \& Sport/Science, Movement \& Health.10(2).

LaGarde G, Doyon J, Brunet A. (2010). Memory and executive dysfunctions associated with acute posttraumatic stress disorder. Psychiatry Research. 177(1-2), 144-49.

Memmert D, Simons DJ, Grimme T. (2009). The relationship between visual attention and expertise in sports. Psychology of Sport and Exercise. 10(1), 146-51.

Özdemir M. (1990). Üniversiteli sporcu ve sporcu olmayan öğrencilerin dikkat seviyelerinin araştırılması. Marmara Üniversitesi Sağlık Bilimleri Enstitüsü Yüksek lisans Tezi.

Schefke T, Gronek P. (2010). Improving attentional processes in sport: defining attention, attentional skills and attention types. Studies in Physical Culture \& Tourism. 17(4).

Sevim Y. (2007). Antrenman bilgisi. Nobel Yayın Dağıtım.

Singer, RN, Cauraugh, JH, Tennant, LK, Murphey, M. (1991). Attention and distractors:Considerations for enhancing sport performances. International Journal of Sport Psychology. 22(2), 95-114.

Solso RL, Maclin MK, Maclin OH. (2007). Bilişsel Psikoloji (Çev. A. Ayçiçeği-Dinn). İstanbul: Kitabevi Yayınları.

Tunç A. (2013). Golf sporu yapan çocukların dikkat düzeylerinin incelenmesi. Selçuk Üniversitesi Sağlık Bilimleri Enstitüsü Doktora Tezi.

Vanhelst J, Béghin L, Duhamel A, Manios Y, Molnar D, De Henauw S, Gottrand F. (2016). Physical activity is associated with attention capacity in adolescents. The Journal of Pediatrics.168, 126-131.

Verburgh L, Königs M, Scherder EJ, Oosterlaan J. (2014). Physical exercise and executive functions in preadolescent children, adolescents and young adults: a meta-analysis . British Journal of Sports Medicine.48(12), 973-79. 